\title{
Trophic upgrading of long-chain polyunsaturated fatty acids by polychaetes: a stable isotope approach using Alitta virens
}

\author{
Supanut Pairohakul ${ }^{1,3} \cdot$ Peter J. W. Olive $^{1} \cdot$ Matthew G. Bentley $^{2} \cdot$ Gary S. Caldwell $^{1}$ (i)
}

Received: 5 August 2019 / Accepted: 4 April 2021 / Published online: 17 April 2021

(c) The Author(s) 2021

\begin{abstract}
Polychaete worms are rich sources of polyunsaturated fatty acids (PUFA) and are increasingly incorporated into aquaculture broodstock diets. Conventionally, the build-up of PUFA in polychaetes was considered passive, with direct accumulation along the food web, originating with microalgae and other primary producers. However, it has been argued that polychaetes (and other multicellular eukaryotes) are capable of PUFA biosynthesis through the elongation and desaturation of precursor lipids. We further test this hypothesis in the ecologically and economically important nereid polychaete Alitta virens by adopting a stable isotope labelling approach. Worms were fed a ${ }^{13} \mathrm{C}-1$-palmitic acid (C16:0) enriched diet with the resulting isotopically enriched lipid products identified over a 7-day period. The data showed strong evidence of lipid elongation and desaturation, but with a high rate of PUFA turnover. A putative biosynthetic pathway is proposed, terminating with docosahexaenoic acid (DHA) via arachidonic (AA) and eicosapentaenoic acids (EPA) and involving a $\Delta 8$ desaturase.
\end{abstract}

\section{Introduction}

Long-chain polyunsaturated fatty acids (PUFA) are essential components in human and animal nutrition. Marine ecosystems have traditionally played prominent roles in PUFA supply; however, overfishing necessitates the development of alternative sources (Arts et al. 2009; Tocher et al. 2019). Aquaculture is a potential route, although this too is limited by supply side deficiency, e.g., for feeds formulation (Tocher 2015). Arachidonic (AA), eicosapentaenoic (EPA) and docosahexaenoic acids (DHA), predominantly produced by photosynthetic algae, are abundant in marine ecosystems (Kelly and Scheibling 2012); however, their biogenic sources are diverse; for instance, they are synthesised by

Responsible Editor: C. Harrod.

Reviewers: undisclosed experts.

Gary S. Caldwell

gary.caldwell@ncl.ac.uk

1 School of Natural and Environmental Sciences, Newcastle University, Newcastle upon Tyne NE1 7RU, UK

2 Newcastle University in Singapore, SIT@ NYP Building, Suntec City 567739, Singapore

3 Present Address: Department of Marine Science, Chulalongkorn University, Bangkok, Thailand bacteria, protists and even by desaturation and chain elongation in many animals (Nichols 2003; Alhazzaa et al. 2011; Hughes et al. 2011; De Troch et al. 2012; Galloway et al. 2013; Kabeya et al. 2018; Galloway and Budge 2020).

The role of marine animals in the de novo synthesis of PUFA is poorly understood. Whereas animals may synthesise palmitate (C16:0) de novo from acetate or acetyl coenzyme A using fatty acid synthase (FAS) (Nelson 1992; Nelson and Cox 2008) to convert palmitic acid to stearic acid (C18:0), and also desaturate palmitic acid and stearic acid into palmitoleic acid (C16:1n7) and oleic acid (C18:1n9), the extent to which further chain elongation and desaturation occurs is variable. When chain elongation and desaturation does take place it creates even numbered fatty acids, which contrasts with the situation found in PUFA synthetic bacteria, where the lipid biosynthesis pathways produce odd numbered and branched chain fatty acids (Kaneda 1991; Metz et al. 2001). Chain elongation of C16 or C18 fatty acids in animals is dependent on the presence of elongase enzymes facilitating chain elongation in the endoplasmic reticulum, by adding two carbon atoms at the carboxyl end of the fatty acid (Kabeya et al. 2018). Desaturation is dependent on desaturase activity. These enzymes are position specific, for example $\Delta 9$ desaturase catalyses the insertion of a double bond at the ninth carbon position from the carboxyl terminal.

The modification of fatty acids along the food web is termed 'trophic repackaging' or 'trophic upgrading' if the 
modification is nutritionally beneficial (Arts et al. 2009). Polychaete annelids (which are ecologically and commercially important) are implicated in this process and it has been suggested that the worms are directly responsible for the chain elongation and desaturation (Olive et al. 2009; Ashforth et al. 2011). Olive and co-workers (Olive et al. 2009) proposed that chain elongation and desaturation to EPA is brought about via the less common $\Delta 8$ pathway-but direct evidence for this is lacking.

Alitta virens (formerly Nereis (Neanthes) virens), one of the dominant errant polychaetes found in the Northern Hemisphere and a useful developmental biology study organism (Kozin and Kostyuchenko 2015; Franz-Odendaal and Hockman 2019), is commonly found in intertidal ecosystems (Kristensen 1984a) and is one of the most important intertidal bioturbators, especially in mudflat systems (Herringshaw et al. 2010) where it plays vital roles in maintaining biodiversity (Tita et al. 2000; McLenaghan et al. 2011; Lacoste et al. 2018), sediment structure (Du Clos et al. 2013), nutrient cycling (Kristensen et al. 1985) and in the accumulation and transfer of pollutants through estuarine food webs (Pini et al. 2015; Watson et al. 2018). Many populations are under stress from bait collection activities (Olive 1993; Watson et al. 2017) that has subsequently driven interest in their aquaculture (Olive 1999). Here we investigate whether chain elongation and desaturation of fatty acids can be traced in $A$. virens by direct feeding with a labelled stable isotope $\left({ }^{13} \mathrm{C}\right.$ palmitic acid, $\left.\mathrm{C} 16: 0\right)$ enriched diet. The occurrence of ${ }^{13} \mathrm{C}$ enriched ion fragments and the consequent shift in the ${ }^{13} \mathrm{C} /{ }^{12} \mathrm{C}$ ratio in fatty acids with a greater chain length and more unsaturation than the administered ${ }^{13} \mathrm{C}$ palmitic acid would provide supporting evidence that chain elongation and desaturation occurs in the worm tissues, thereby supporting the trophic repackaging hypothesis, providing new insight into polychaete nutrition, and potentially for the flow of PUFA in intertidal soft sediment systems.

\section{Materials and methods}

\section{Animal origin and culture conditions for fatty acids net change}

Alitta virens were collected from the estuary of the River Blyth, Northumberland, UK (grid reference: NZ 30985 81139). All animals were immediately transported to the laboratory where they were depurated for $24 \mathrm{~h}$ in artificial seawater at $12 \pm 0.1{ }^{\circ} \mathrm{C}$. A wet weight to dry weight (freeze dried) conversion was determined for depurated whole worms $(n=20)$ covering a range of sizes.

Plastic tanks $(30 \times 20 \times 15 \mathrm{~cm})$ were pre-conditioned for 1 week by adding a layer of cleaned and sieved sand substrate from Cullercoats Bay, Northumberland, UK (grid reference: NZ 36340 71268). Twelve worms of mean individual wet weight of $1 \mathrm{~g}$ were put into each of six tanks containing $9 \mathrm{~cm}$ of cleaned and sieved sand. Ten worms were immediately snap frozen in liquid nitrogen and stored at $-80{ }^{\circ} \mathrm{C}$ under nitrogen to provide a baseline tissue fatty acid profile (Fig. 1a). Polychaetes in three tanks were fed sterilised formulated feed pellets daily (fed: $n=3$ ) while the polychaetes in the remaining three tanks were unfed (unfed: $n=3$ ). The three worms were randomly sampled and their fatty acid contents profiled. The diets comprised fish meal, soya bean meal and cereals and were sufficient for normal development of the worms. The fatty acid profile of the pellets is presented in Fig. 1b. Worms were fed a ration of $0.2 \%$ of body wet weight per day, adjusted on a weekly basis to a final ration of $0.045 \mathrm{~g}$ per day at the end of the experimental period. The feed ration was sufficient for growth without excess food waste (Islam 2001).

The trials were run for 60 days whereupon all worms were removed, depurated for $24 \mathrm{~h}$, individually weighed and frozen at $-80{ }^{\circ} \mathrm{C}$ for subsequent FAME (fatty acid methyl ester) analysis. The remaining sand was homogenised and stored as per the worms.

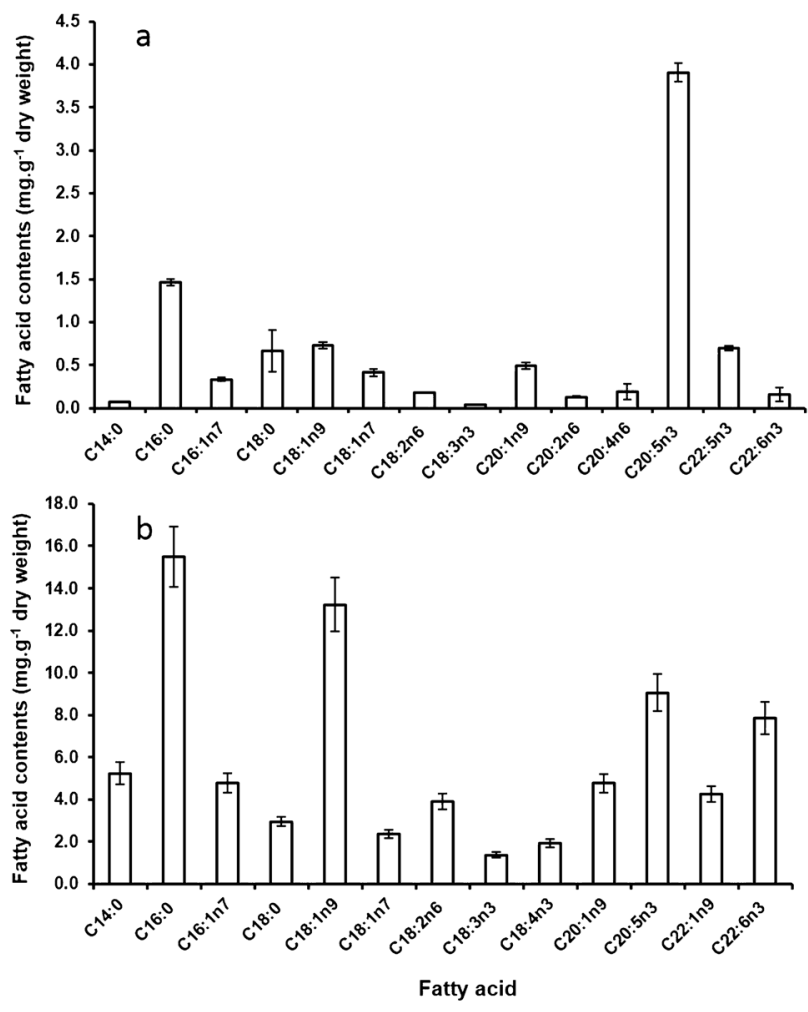

Fig. 1 Fatty acid contents (mean $\pm 95 \%$ confidence interval, $n=10$ ) of $\mathbf{a}$ the initial Alitta virens tissue samples, and $\mathbf{b}$ of the formulated pellet feed 


\section{Stable isotope labelling experiment}

Separate to the net gain experiment, labelled food was administered daily for 7 days. The food was prepared by adding $125 \mathrm{mg}$ of ${ }^{13} \mathrm{C}$-1-palmitic acid (C16:0) (Sigma Aldrich, $\mathrm{UK}$ ) in methanol to $5 \mathrm{~g}$ of ground feed pellets (Pairohakul 2013). These were re-pelletised and dried at $200{ }^{\circ} \mathrm{C}$ for $3 \mathrm{~h}$ to make a stock of ${ }^{13} \mathrm{C}$ palmitate enriched feed pellets $\left(25 \mathrm{mg} \mathrm{g}^{-1}\right)$. Worms with an average weight of $1 \mathrm{~g}$ were placed individually into separate glass crystallising dishes with a $2 \mathrm{~cm}$ depth of cleaned and sieved sand and acclimated for 7 days under the same animal husbandry conditions as described in the fatty acid net change trials.

Post-acclimation, the worms were grouped into two treatments (labelled and unlabelled), with each worm remaining isolated within an individual crystallising dish, i.e., each worm is considered to be an independent replicate within a treatment. Each worm was fed daily with $0.02 \mathrm{~g}$ of feed pellets in two groups, one given ${ }^{13} \mathrm{C}$-labelled palmitate food pellets (labelled food group) and a second group was given normal unlabelled food pellets (unlabelled food group). Four worms from each treatment group were sampled on days 1, 3, 5 and 7 to determine the between-worm error terms for subsequent statistical comparisons. Similarly, four worms were sampled at day 0 . The fatty acid composition of the fish feed pellets was analysed to permit a comparison between the normal feed diets and the labelled feed following incorporation of ${ }^{13} \mathrm{C}$-labelled palmitate. All worm and feed pellet samples were kept at $-80{ }^{\circ} \mathrm{C}$ prior to analysis.

\section{Lipid extraction and FAME conversion}

Worm and diet samples were lyophilised for $48 \mathrm{~h}$ prior to lipid extraction. Twenty worm samples were individually weighed before and after lyophilisation to determine a regression analysis equation for fatty acid gain and loss. Lipids were extracted overnight using a modified Folch method (Folch et al. 1957). All glassware was acetone rinsed and dried overnight at $200{ }^{\circ} \mathrm{C}$. Samples were homogenised with methanol for $1 \mathrm{~min}$ followed by chloroform addition $(1: 2 \mathrm{v} / \mathrm{v})$ and vortexed for $1 \mathrm{~min}$. Samples were kept refrigerated overnight (approximately $16 \mathrm{~h}$ ) in Pyrex tubes fitted with PTFE liner caps under a nitrogen atmosphere. After overnight extraction the samples (dry masses of between 0.2 and $0.5 \mathrm{~g}$ ) were vacuum-filtered through Whatman $2 \mathrm{E}$ filter papers and $0.5 \mathrm{ml}$ of $\mathrm{C} 19: 0\left(0.5 \mathrm{mg} \mathrm{ml}^{-1}\right.$ in hexane $)$ was added as an internal standard for gas chromatography analysis (Islam 2001), followed by a $0.88 \% \mathrm{w} / \mathrm{v} \mathrm{KCl}$ solution filled to $25 \%$ of the pre-filtering starting volume. The samples were vortexed and left to separate. The lower layer was collected and evaporated under a nitrogen stream at $37{ }^{\circ} \mathrm{C}$ until dry.
The extracted lipids were transesterified to FAME by acid-catalysis (Christie 1993). The dried lipids were resuspended in $1 \mathrm{ml}$ toluene and $2 \mathrm{ml}$ of $1 \%$ sulphuric acid in methanol, flushed with nitrogen gas to prevent oxidation, vortexed and incubated at $80{ }^{\circ} \mathrm{C}$ for $1 \mathrm{~h}$. After cooling, $2 \mathrm{ml}$ of $2 \% \mathrm{w} / \mathrm{v} \mathrm{KHCO}_{3}$ with $5 \mathrm{ml}$ of hexane: diethylether $(1: 1, \mathrm{v} / \mathrm{v})$ were added and allowed to separate. The upper layer was transferred to a new clean tube. A further hexane: diethylether extraction was performed. The pooled upper layer was evaporated under nitrogen at $37{ }^{\circ} \mathrm{C}$ until dry. Dried FAME were resuspended in $1.5 \mathrm{ml}$ hexane, transferred to GC vials, and kept frozen under nitrogen at $-20^{\circ} \mathrm{C}$ prior to GC or GC/MS analysis.

Samples were analysed using an Agilent 7890A gas chromatograph (GC) fitted with an Agilent DB23 fused silica capillary column $(30 \mathrm{~m} \times 0.25 \mathrm{~mm}$ I.D. $\times 0.25 \mu \mathrm{m}$ film thickness) and interfaced to an Agilent 5975C Mass Select Detector (MSD). Samples were injected on to the GC column in pulsed splitless mode (1 min splitless at $150 \mathrm{kPa}$ inlet pressure, then $30 \mathrm{ml} \mathrm{min}{ }^{-1}$ split) using an Agilent 7683B automatic injector. The GC inlet temperature was $280{ }^{\circ} \mathrm{C}$ and the GCMS interface temperature was $220^{\circ} \mathrm{C}$. Helium was used as carrier gas at a constant flow rate of $1 \mathrm{ml} \mathrm{min}{ }^{-1}$. The $\mathrm{GC}$ oven was heated from $60{ }^{\circ} \mathrm{C}$ (initial hold time $1 \mathrm{~min}$ ) to $140{ }^{\circ} \mathrm{C}$ (hold time $3 \mathrm{~min}$ ) at $20^{\circ} \mathrm{C} \mathrm{min}^{-1}$, then at $10{ }^{\circ} \mathrm{C} \mathrm{min}{ }^{-1}$ to $190{ }^{\circ} \mathrm{C}$ (hold time $3 \mathrm{~min}$ ), then at $10{ }^{\circ} \mathrm{C} \mathrm{min}-1$ to $220{ }^{\circ} \mathrm{C}$ (final hold time $18 \mathrm{~min}$ ). The MSD was operated in electron impact mode (electron voltage $70 \mathrm{eV}$, source temperature $230^{\circ} \mathrm{C}$, quad temperature $150^{\circ} \mathrm{C}$, multiplier voltage ca. $1800 \mathrm{~V}$ ). Data were acquired using Agilent ChemStation software, operating in full scan mode (range 50-600 amu sec ${ }^{-1}$ ) or selected ion monitoring mode (30 ions, $0.8 \mathrm{cps}, 35 \mathrm{~ms}$ dwell time) after a solvent delay of 5 min. Data processing was performed using ChemStation software and peaks were identified, where possible, by comparison of mass spectra with those in the NIST05 mass spectra library or in the published literature. To trace the change in the ${ }^{13} \mathrm{C} /{ }^{12} \mathrm{C}$ ratio after administration of ${ }^{13} \mathrm{C}$ labelled food, the ion peaks of interest in the mass spectra were extracted using the command 'extract ion chromatography' using an $\mathrm{m} / \mathrm{z}$ range from 0.30 to 0.70 in the ChemStation program. The extracted peaks were integrated to determine their own peak area. The integration threshold was set at $7.5 \mathrm{mV}$ to detect the small changes in all longer fragment peak area. The peak area of the characteristic ion peak with normal ${ }^{12} \mathrm{C}$ and ion peak with labelled ${ }^{13} \mathrm{C}$ of the same fragment was calculated to determine the ${ }^{13} \mathrm{C} /{ }^{12} \mathrm{C}$ isotope ratio.

Four external standards were used for retention time analysis of each fatty acid: (1) Sigma cod liver oil, (2) GLC$538 \mathrm{Nu}$-Chek prep standard, (3) a single FAME of C18:3n6 $(\gamma$-linolenic acid) and (4) a single FAME of C20:2n6 (eicosadienoic acid). All external standards were run in the same condition as the samples. The peak area of each fatty acid 
was calculated using the Thermo Scientific Atlas Chromatography Data System program. Fatty acid quantification was determined by comparing each individual peak with a known amount of internal standard (C19:0).

FAMEs were ionised using electron impact ionization (EI). The molecular fragments were then identified using mass-to-charge ratio $(\mathrm{m} / \mathrm{z})$ from the fragments derived from EI to compare the changes in fatty acid composition. The differences in ${ }^{13} \mathrm{C} /{ }^{12} \mathrm{C}$ ratio in each molecular significant fragment were determined. An increase of one in the number of neutrons in the stable isotope $\left({ }^{13} \mathrm{C}\right)$ will lead to an increase in one unit of $\mathrm{m} / \mathrm{z}$ ratio of the fragment (Burdge and Calder 2005; Malcicka et al. 2017; Wilkinson 2018). Therefore, the signal strength of one more atomic mass for each fragment ion will be increased; consequently, an enhancement of the ${ }^{13} \mathrm{C} /{ }^{12} \mathrm{C}$ ratio indicates the presence of ${ }^{13} \mathrm{C}$ in the metabolites. The interpretation of the molecular fragments derived from the MS were adopted mainly from the lipid library AOCS (http://lipidlibrary.aocs.org) and from Silverstein et al. 2005 and Dass 2007 (Silverstein et al. 2005; Dass 2007).

\section{Statistical analysis}

Mortality rate, specific growth rate (SGR), percentage weight gain (PWG) and absolute growth rate (AGR) were calculated across treatments according to Lazo and Davis (Lazo and Davis 2000). Fatty acid gain or loss was compared by converting the quantity of fatty acid $\left(\mathrm{mg} \mathrm{g}^{-1}\right.$ dry weight) to an estimated quantity relative to the wet weight as it was not possible to determine initial values in the exact worms added to the tanks. Accordingly, regression equations between wet weight and dry weight of 13 worms of each species were determined. Each fatty acid was then converted from $\mathrm{mg} \mathrm{g}^{-1}$ dry weight into the estimated equivalent $\mathrm{mg} \mathrm{g}^{-1}$ wet weight to compare the net gain or loss of any fatty acid in relation to worm biomass (wet weight). The net change of each fatty acid was then calculated in terms of total worm wet weight biomass using Eq. (1). The 'FEED' term was determined by multiplying the quantity of food added and fatty acid content in terms of $g$ dry weight. A principle component analysis (PCA) was conducted using the prcomp function in RStudio. The package ggbiplot was used to plot and scale these values into the PCA. PC1 and PC2 were used as they accounted for $98.47 \%$ of the total variability in the data.

Fatty acid change $=$ fatty acid of worm $($ END - START - FEED $)$

Where: START $=$ (fatty acids in $\mathrm{g}$ wet weight $\times$ number of surviving worms $\times$ mean worm biomass before the experiment $) ; \mathrm{END}=($ fatty acids in $\mathrm{g}$ wet weight $\times$ number of surviving worms $\times$ mean worm biomass after the experiment);
FEED $=($ fatty acids in $\mathrm{g}$ dry weight $\times$ quantity of added feed pellet over the period of the experiment).

The START term was calculated using the number of surviving worms after the experiment, multiplied by the average worm weight at the start of the experiment rather than the average weight at the start multiplied by the number of animals added at the start to allow for the fact that in a few tanks a small number of animals died over the course of the experiment. Failure to allow for mortality would tend to underestimate any net gain. In adopting this procedure, the assumption is made as if all mortalities occurred during the first day of the experiment. This assumption was met as most of the deaths occurred early in the experiment (within $48 \mathrm{~h}$ ). The quantity of fatty acids in the sand prior to feed addition and in the homogenised sand after the completion of the experiment was below the detection limits of the GC procedures and was taken to be zero. The FEED term therefore was the only value used for calculating the exact net gain or loss of each fatty acid during the experiment.

SPSS version 17.0 was used for statistical analyses. Growth data were analysed by independent $t$ tests. A oneway analysis of variance (one-way ANOVA) was used to compare the changes between control and experimental samples on different time periods after intake of ${ }^{13} \mathrm{C}$-labelled palmitic acid. A Dunnett's $t$ test was used to determine the difference of each experimental group against the control group. The samples obtained from the beginning of the experiment were set as a control group in the Dunnett's multiple comparison. A one-tailed test was also used to confirm any increase of fatty acid metabolites after ${ }^{13} \mathrm{C}$-labelled precursor uptake by the worms as any increase will indicate the production of fatty acid within the worms.

\section{Results}

\section{Net change of fatty acids}

Worms in the fed treatment more than tripled their body mass over the course of the experiment, whereas the unfed controls lost approximately 50\% (Table 1), with an associated greater mortality rate. The relationship between wet and dry weight for $A$. virens was described by a linear regression: dry weight $=0.2203$ wet weight -0.0269 $\left(r^{2}=0.9953, n=20, p<0.001\right)$. There was a net gain in most fatty acids for the fed A. virens (Fig. 2 and Fig. S1). Cis-vaccenic acid $(\mathrm{C} 18: 1 \mathrm{n} 7)$ increased the most, with marked gains in oleic acid (C18:1n9) and EPA (C20:5n3). There was a net gain in eicosadienoic acid (C20:2n6), with DHA (C22:6n3) also increased but to a lesser degree. There were also clear gains in palmitoleic acid (C16:1n7) and linoleic acid (C18:2n6). There was a net loss of myristic acid (C14:0), $\alpha$-linolenic acid (C18:3n3) and 
Table 1 Growth and mortality data for Alitta virens at the beginning and end of the 60-day fatty acid net change trial

\begin{tabular}{|c|c|c|c|c|c|c|}
\hline & \multicolumn{3}{|l|}{ Fed tanks } & \multicolumn{3}{|l|}{ Unfed tanks } \\
\hline & Tank 1 & Tank 2 & Tank 3 & Tank 4 & Tank 5 & Tank 6 \\
\hline Initial wet weight $(\mathrm{g})$ & $1.059 \pm 0.640^{\mathrm{a}}$ & $1.090 \pm 0.788^{\mathrm{a}}$ & $0.921 \pm 0.425^{\mathrm{a}}$ & $1.014 \pm 0.731^{\mathrm{a}}$ & $0.829 \pm 0.418^{\mathrm{a}}$ & $0.842 \pm 0.554^{\mathrm{a}}$ \\
\hline Final wet weight $(\mathrm{g})$ & $3.678 \pm 1.315^{\mathrm{b}}$ & $3.493 \pm 1.407^{\mathrm{b}}$ & $3.907 \pm 1.280^{\mathrm{b}}$ & $0.633 \pm 0.566^{\mathrm{a}}$ & $0.623 \pm 0.550^{\mathrm{a}}$ & $0.608 \pm 0.358^{\mathrm{a}}$ \\
\hline Mortality (\%) & 16.67 & 16.67 & 8.33 & 8.33 & 41.67 & 25 \\
\hline SGR $\left(\%\right.$ day $\left.^{-1}\right)$ & 2.074 & 1.942 & 2.408 & -0.783 & -0.482 & -0.542 \\
\hline SGR $\left(\%\right.$ day $^{-1}$ survived worm $\left.{ }^{-1}\right)$ & 0.207 & 0.194 & 0.219 & -0.071 & -0.002 & -0.060 \\
\hline PWG $(\%)$ & 247.186 & 220.578 & 324.077 & -37.475 & -25.127 & -27.753 \\
\hline $\operatorname{AGR}\left(\mathrm{mg} \mathrm{day}^{-1}\right)$ & 43.628 & 40.053 & 49.735 & -6.328 & -3.473 & -3.885 \\
\hline $\operatorname{AGR}\left(\mathrm{mg} \mathrm{day}^{-1}\right.$ survived worm $\left.{ }^{-1}\right)$ & 4.363 & 4.005 & 4.521 & -0.575 & -0.496 & -0.431 \\
\hline
\end{tabular}

Tanks 1-3: Treatments fed with a formulated pellet feed; tanks 4-6: unfed controls

Biomass was measured as wet weight, $S G R$ specific growth rate, $P W G$ percentage weight gain, $A G R$ absolute growth rate Initial and final weight data are in terms of mean $\pm 95 \%$ confidence intervals; differing letters following the numbers indicate statistical differences between groups $(p<0.05)$

Fig. 2 The net gain or loss (mean $\pm 95 \%$ confidence interval) of each selected fatty acid in Alitta virens after 60 days relative to the fatty acid content of the starting population less the fatty acid content from the formulated pellet feed

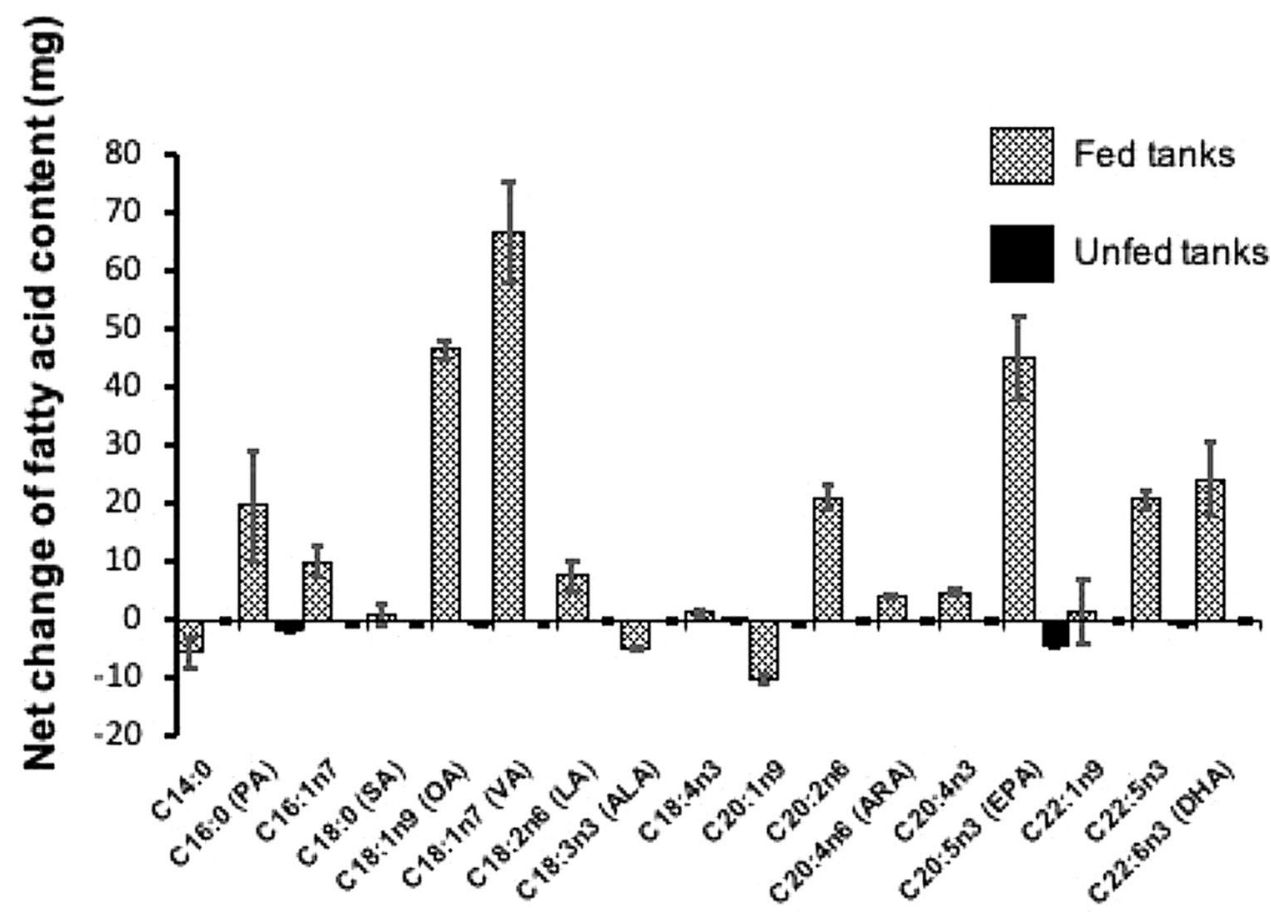

Fatty acid 11-eicosenoic acid (C20:1n9). In the unfed groups, there was a net loss of all fatty acids (albeit minor), with EPA $(\mathrm{C} 20: 5 \mathrm{n} 3)$ suffering the greatest loss.

The overall pattern in the ${ }^{13} \mathrm{C} /{ }^{12} \mathrm{C}$ ratio for the fragment peaks of interest for each fatty acid is shown in Fig. 3. Evidence of changes in the ratios of some interesting FAME intermediates such as methyl $\alpha$-linolenate (C18:3n3), $\gamma$-linolenate (C18:3n6) and methyl dihomo- $\alpha$-linolenate (C20:3n6) were indicated; however, these intermediaries were present only in trace amounts and could not be consistently distinguished from the background noise.
The statistical data for the characteristic ion peaks from the repeated feeding experiment are summarised in supplementary materials (Tables S1-S8). There was a significant increase in the ${ }^{13} \mathrm{C} /{ }^{12} \mathrm{C}$ ratio for each of the three characteristic fragment peak ions for methyl palmitate (C16:0) (one way ANOVA: McLafferty ion $(m / z=75: 74), F(2,27)=12.426$, $p<0.001$; loss of the methoxy ion $(\mathrm{m} / \mathrm{z}=240: 239), F(2$, $27)=11.881, p<0.001$; molecular peak $(m / z=271: 270)$, $F(2,27)=12.751, p<0.001)$ (Table S1). A Dunnett's $t$ multiple comparison of the molecular peaks in all samples groups indicated that all the samples in the labelled groups 
Fig. 3. ${ }^{13} \mathrm{C} /{ }^{12} \mathrm{C}$ ratios (means \pm standard deviation) of selected fragment ions for some important FAME. The molecular peaks were adopted in palmitic acid (C16:0), stearic acid (C18:0) and linoleic acid (C18:2n6). The $\alpha$-ions were selected for arachidonic acid (C20:4n6), eicosapentaenoic acid (C20:5n3) and docosahexaenoic acid (C22:6n3). The loss of the McLafferty ion was used for oleic acid (C18:1n9) while the loss of the methoxy ion is shown in the case of eicosadienoic acid (C20:2n6). An asterisk (*) is attached to bars with a $p$ value less than $0.05(p<0.05)$ obtained from a Dunnett's $t$ post hoc test. $\mathrm{L}$ is abbreviated for labelled pellet fed tanks whereas $\mathrm{C}$ is abbreviated for normal pellet fed tanks

had a significantly greater ratio compared with the control $(p<0.01)$. None of the isotope ratios in the unlabelled group differed significantly from the control group indicating that the labelled palmitate had been absorbed and was detectable in the worm tissues.

For the ${ }^{13} \mathrm{C} /{ }^{12} \mathrm{C}$ ratio of the three characteristic peaks for methyl stearate $(\mathrm{C} 18: 0)$, the molecular peak $(\mathrm{m} / \mathrm{z}=299: 298)$ was significantly different $(F(2,27)=7.812, p<0.001)$. A Dunnett's $t$ comparison showed a significant difference compared with the day zero control for days 3,5 and 7 in the labelled fed group $(p<0.05)$. However, there was no evidence to support a significant difference compared with the control for day 1 samples in the labelled group and all samples from the unlabelled feed group. Interestingly, the isotope ratio for the first hydrocarbon series $(\mathrm{m} / \mathrm{z}=88: 87)$ changed in a similar way to that observed for the molecular peak and significant differences to the day zero control were observed for the samples at days 3, 5 and 7 (Table S2). However, differences between sample means for the McLafferty ion ratio $(m / z=75: 74)$ compared with the control were not statistically significant (Dunnett's $t$ post hoc test $p>0.05$ ). The data indicate that chain elongation from $\mathrm{C} 16: 0$ to $\mathrm{C} 18: 0$ does occur within worm tissues.

For methyl oleate (C18:1n9), the loss of the methanol $\left([\mathrm{M}-32]^{+}, m / z=265: 264\right)$ and McLafferty ion peaks ([M$\left.74]^{+}, m / z=223: 222\right)$ were analysed as representative fragment peak ions. In contrast to methyl palmitate and stearate, there were no significant differences between means (Table S3). The molecular peak ratio $(\mathrm{m} / \mathrm{z}=297: 297)$ could not be detected on the spectra due to background noise.

Only the molecular peak $(\mathrm{m} / \mathrm{z}=295: 294)$ for methyl linoleate $(\mathrm{C} 18: 2 \mathrm{n} 6)$ was detected other than in trace quantities. There were no significant differences between each groups $(F(2,27)=2.335, p=0.057)$ (Table S4). For methyl eicosadienoate (C20:2n6), neither the loss of the methoxy ion $\left.[\mathrm{M}-31]^{+}, m / z=292: 291\right)$ nor the molecular peak $\left([\mathrm{M}]^{+}, m / z=323: 322\right)$ showed any significant change (Table S5).

The ${ }^{13} \mathrm{C} /{ }^{12} \mathrm{C}$ ratio for the $\alpha$-ion $(\mathrm{m} / z=181: 180)$ from methyl arachidonate (C20:4n6) was significantly increased on day 3 and day $5(F(2,27)=3.145$ and $p=0.013)$, also supported by a Dunnett's t test (day $3, p=0.001$; day 5 , $p=0.047)$ (Table S6).

The $\alpha$-ion $(m / z=181: 180)$ from methyl eicosapentaenoate EPA $(\mathrm{C} 20: 5 \mathrm{n} 3)$ increased significantly $(F(2,27)=2.743$, $p=0.024)$. The ${ }^{13} \mathrm{C} /{ }^{12} \mathrm{C}$ ratio increased to $0.252 \pm 0.015$ from a baseline of $0.225 \pm 0.004$ within only 1 day. However, the isotopic ratio was not significantly increased in samples taken after $24 \mathrm{~h}$ (Table S7). The data indicate that ${ }^{13} \mathrm{C}$ is incorporated into EPA around $24 \mathrm{~h}$ after administration, but the signal is subsequently dissipated.

In contrast to methyl arachidonate and methyl eicosapentaenoate, there was no evidence of an increase of the ${ }^{13} \mathrm{C} /{ }^{12} \mathrm{C}$ ratio in the $\alpha$-ion $(m / z=167: 166)$ of methyl docosahexaenoate, DHA (C22:6n3) over the experimental period $(F(2$, $27)=1.078, p=0.407)($ Table S8).

\section{Discussion}

Alitta virens has demonstrated the capacity to accumulate and produce some PUFA within a closed culture system, as has previously been shown for the polychaete Arenicola marina (Olive et al. 2009). These species are often the 
dominant infauna over large areas of intertidal beaches and mudflats, therefore such production may be ecologically significant and should be a target for further development for aquaculture. We sought to provide further clarity on PUFA bioaccumulation and biosynthesis by adopting a pulse-chase strategy using stable isotopes. Pulse-chase experiments have proven useful in understanding and quantifying numerous biochemical pathways (Levis and Penman 1977; Bostrom et al. 1986; Aberle and Witte 2003; Fuchs et al. 2010), including lipid metabolism (He et al. 1987; de Kroon 2017), and has been widely applied in marine trophodynamic studies (Bell et al. 2007; Pitt et al. 2009; Seemann et al. 2013; Miyatake et al. 2014; Oakes et al. 2016; Riekenberg et al. 2018). The worms were fed a ${ }^{13} \mathrm{C}$-1-palmitic acid (C16:0) enriched diet, therefore lipids (other than palmitic acid) that were identified with a ${ }^{13} \mathrm{C}$ label must have been synthesized from the labelled palmitic acid precursor. The label can also be used to study lipid accumulation. Overall net gains in several PUFA were observed, e.g., a $40-50 \mathrm{mg} \mathrm{g}^{-1}$ net gain of EPA, which agrees with Brown et al. (2011), and as a proportion of this EPA was ${ }^{13} \mathrm{C}$ labelled it must have originated from introduced $\mathrm{C} 16: 0$. The proportion of labelled versus unlabelled EPA can be used to differentiate between EPA biosynthesis, turnover and bioaccumulation (Supplementary Table S7). EPA is a dominant fatty acid in the related nereidid species, Hediste diversicolor (Fidalgo e Costa 1999; Bischoff et al. 2009) suggesting that $H$. diversicolor in addition to $A$. virens and A. marina may also biosynthesise EPA de novo when fed low-EPA content diets. However, caution must be used given the limited period of the labelling study as the findings may represent short to medium term responses rather than a long-term response in EPA metabolic flux. Further studies using pulse-chase experiments over longer periods are needed; however, these would need to be carefully designed to support extended worm cultivation while minimising contributions to fatty acid biosynthesis from sediment-associated bacteria (supporting worm survival for $60+$ days without sediment is a non-trivial task).

Brown et al. (2011) found that palmitic acid (C16:0), oleic acid (C18:1n9) and linoleic acid (C18:2n6) are present in high concentrations in the worm tissues; the net gains of palmitic and oleic acids observed by us were also high. The gain in linoleic acid was however relatively small, possibly because sufficient linoleic acid for the worm's growth was present in the feed. There was a small, but nonetheless noticeable gain of DHA (C22:6n 3$)$ and other $\mathrm{C}_{22}$ intermediates such as $\mathrm{C} 22: 5 \mathrm{n} 3$. These species were present in the initial samples in trace amounts. García-Alonso et al. (2008) also reported that DHA was present in $H$. diversicolor and its presence was independent of the presence of this fatty acid in the food source.

This evidence indicates that Nereididae may be capable of synthesising some key long-chain unsaturated fatty acids, implying some mechanism for chain elongation and desaturation occurs; however, for confirmation, further follow up feeding trials using controlled delipidated diets are needed. Chain elongation and desaturation were observed when ${ }^{13} \mathrm{C}$ enriched palmitic acid was administered, most notably through the appearance of enriched isotopic fractions of EPA. The observed increase in the isotopic ratio of methyl stearate (C18:0) could only result from a conversion of the labelled C16:0 to C18:0, providing strong evidence that this chain elongation occurs within the worm tissues. The increase in the ${ }^{13} \mathrm{C} /{ }^{12} \mathrm{C}$ ratio for methyl EPA $(\mathrm{C} 20: 5 \mathrm{n} 3)$ provides evidence consistent with the hypothesis that desaturation also occurs within the worm tissues.

Most of the possible intermediate fatty acid metabolites were considered and analysed; however, it was not possible to trace changes in the signature of all fatty acid metabolites because they were present only in relatively small amounts or, in some cases, were absent or masked by background noise. The two characteristic peaks for methyl stearate (C18:0) were significantly higher on days 3 and 5. Chain elongation involves the addition of two carbons at the carboxyl end of the fatty acid molecule in accordance with the concept that fatty acid elongation from palmitic acid (C16:0) to stearic acid (C18:0) occurs in all organisms (Nelson and Cox 2008; Berg et al. 2012).

Analysis of the pathways for subsequent conversion is based on the examination of isotopic ratios for all fatty acids present. Greater importance is attached to positive observations (i.e., the observation of a statistically significant change in the isotopic ratio) than to negative ones since conversion of fatty acids may occur quickly and intermediaries may not persist in time. In effect, we only have a series of 'snap shots' taken during relatively long time intervals (days), and many entities are likely to be found only at very low concentrations that are not easily distinguished from background levels. Accordingly, while no changes in the isotope ratios of oleic (C18:1n9) and linoleic acids (C18:2n6) were observed, the significant changes in putative 'downstream' entities is considered to be of critical importance in the interpretation of the data. The problem of low tissue concentrations is exemplified with respect to methyl $\alpha$-linolenate $(\mathrm{C} 18: 3 \mathrm{n} 3)$ and $\gamma$-linolenate (C18:3n6) which, if present, were below the detection threshold.

A significant change in the ${ }^{13} \mathrm{C} /{ }^{12} \mathrm{C}$ of the $\alpha$-ion for methyl arachidonate (C20:4n6) was observed on days 3 and 5, demonstrating that $A$. virens can synthesise arachidonic acid from shorter carbon chain, less saturated substrate molecules. Arachidonic acid is a precursor of eicosanoids and their derivatives such as prostaglandins (Stanley and Howard 1998; Stanley 2000), which play important roles in immunity, reproductive physiology and ion transport in several invertebrates (Stanley 2000). Eicosanoid biosynthesis involves three different pathways: (i) the cyclooxygenase 
pathway which produces prostaglandins; (ii) the lipoxygenase pathway which generates leukotriene and lipoxin; and (iii) the epoxygenase pathway for prostaglandin, thromboxane and prostacyclin biosynthesis. The cyclooxygenase pathway has been suggested to be an important eicosanoid pathway in polychaetes (Meunpol et al. 2005, 2010). Bentley et al. (1990) and Bentley and Hardege (1996) have also suggested a reproductive function for arachidonic acid together with dihomo- $\alpha$-linoleate $(\mathrm{C} 20: 3 \mathrm{n} 6)$ which act as oocyte maturation hormones.

To build a picture of the EPA biosynthesis pathways from shorter chain less saturated fatty acids in A. virens, we draw upon our measurements of the accumulation of specific fatty acids in the culture system coupled with the isotopic labeling data. This species can elongate palmitate $(\mathrm{C} 16: 0)$ to stearate (C18:0) by adding two carbons at the carboxyl end, as per other eukaryotes. In culture, we also observed net accumulation of the monoenoic acids palmitoleic acid (C16:1n7), vaccenic acid (C18:1n7) and oleic acid (C18:1n9), of which vaccenic and oleic acid production were particularly prominent. Bischoff et al. (2009) found that tissue concentrations of both vaccenic and oleic acids were high in wild-caught and cultured Hediste diversicolor, as also found in Perinereis nuntia (Limsuwatthanathamrong et al. 2012). These observations suggest that Nereididae are generally able to actively maintain their characteristic monoene fatty acid profile. Linoleic acid (C18:2n6) accumulated over the period of the experiment but there was a net loss of $\alpha$-linolenic acid (ALA, C18:3n3), one of the so called 'essential fatty acids' and precursor of the $\mathrm{n} 3$ series. ALA was not detected in $P$. nuntia (Limsuwatthanathamrong et al. 2012) nor in wild caught $H$. diversicolor (García-Alonso et al. 2008; Bischoff et al. 2009) and the low importance of ALA in Nereididae is further confirmed by our labelling experiments since ALA was undetected although very small quantities of linoleic acid (C18:2n6) were found. We conclude that ALA is not an important fatty acid in nereidid worm species and it is likely that the desaturation step from linoleic acid to ALA is relatively unimportant.

Distinguishing between two key intermediates, $\gamma$-linolenic acid (C18:3n6) and eicosadienoic acid (C20:2n6), is critical to determine the more likely PUFA biosynthetic pathways in $A$. virens. Of the two, only eicosadienoic acid was detected in the labelling experiment, suggesting that C20:2n6 is the more important intermediate. A virtual absence of $\alpha$-linolenic acid has been found in all studies of polychaete taxa so far (Duangchinda 2007; García-Alonso et al. 2008; Bischoff et al. 2009; Brown et al. 2011; Limsuwatthanathamrong et al. 2012). The absence of this fatty acid is a clear indication that $A$. virens utilises the alternative $\Delta 8$ pathway to synthesise long-chain PUFA as suggested by Olive et al. (Olive et al. 2009) for Arenicola marina. We did not observe significant changes in the ${ }^{13} \mathrm{C} /{ }^{12} \mathrm{C}$ ratio of the characteristic mass spectrum peaks of $\mathrm{C} 20: 2 \mathrm{n} 6$, but failure to detect such differences may be because the intermediate fatty acids in a pathway may be present only for a very short period and transient changes in the isotope ratio may not be detected given the sampling times used. Notwithstanding this difficulty, we consider the 'alternative' $\Delta 8$ pathway to be the most likely PUFA biosynthetic pathway and, on the basis of the evidence discussed here, we suggest a set of likely PUFA biosynthetic pathways in A. virens (Fig. 4). Confirmation requires study of the proposed $\Delta 8$ and $\Delta 5$ desaturase activity and of the $\Delta 4$ desaturase pathway to establish whether or not A. virens can synthesise DHA from EPA.

The simplest interpretation of such changes is that they could be driven by undetected commensal organisms, e.g., a gut microbiome community (Dale et al. 2019; Hochstein et al. 2019); however, evidence is accumulating that enzymes coded in the worm genome could account for the differences (Monroig et al. 2013; Liu et al. 2017; Kabeya et al. 2018). If dominant infaunal animals such as Alitta virens can synthesise substantial quantities of fatty acids such as EPA, some revision of our understanding of lipid biosynthesis in marine ecosystems may be necessary. A perception remains-although it is being robustly challenged (Monroig et al. 2013; Kabeya et al. 2018) — that the majority of animals are incapable of producing PUFA from more saturated precursors (Bell and Tocher 2009). Our observations, although not specifically determining PUFA biosynthesis directly, tend not to support the traditional thesis. For example, Caenorhabditis elegans is capable of synthesising EPA from $\mathrm{C}_{16}$ substrates via a $\Delta 12$ desaturase (Watts and Browse 2002; Watts 2009; Menzel et al. 2019) and similar capability has been demonstrated for a number of insect species (Stanley-Samuelson 1987; Blomquist et al. 1991). Further, genomic analysis shows that desaturases and elongases are widespread throughout the animal kingdom, and these enzymes classes are present in the genome of the polychaete Capitella, the first for which a complete genome has been published (Simakov et al. 2013). However, functional diversification has occurred (Hashimoto et al. 2006, 2008), and the ability to synthesise fatty acids varies throughout the eukaryotic domain (Kabeya et al. 2018).

The $\Delta 5$ desaturase gene in Octopus vulgaris has similar amino acid sequences to bivalve (Crassostrea gigas) and gastropod (Lottia gigantia) molluscs, but low similarity with less related invertebrates (Monroig et al. 2012b), plus a $\Delta 12$ desaturase has now been identified in $O$. vulgaris (Garrido et al. 2019). However the elongase amino acid sequence in the same species of octopus was very similar to those of other eukaryotes (Monroig et al. 2012a). Further, $\Delta 5$ and $\Delta 6$ fatty acyl desaturases have recently been implicated in PUFA biosynthesis in the aquacultured razor clam Sinonovacula constricta alongside novel elongases (Ran et al. 2019). The observed pattern of fatty acid profiles in different organisms 


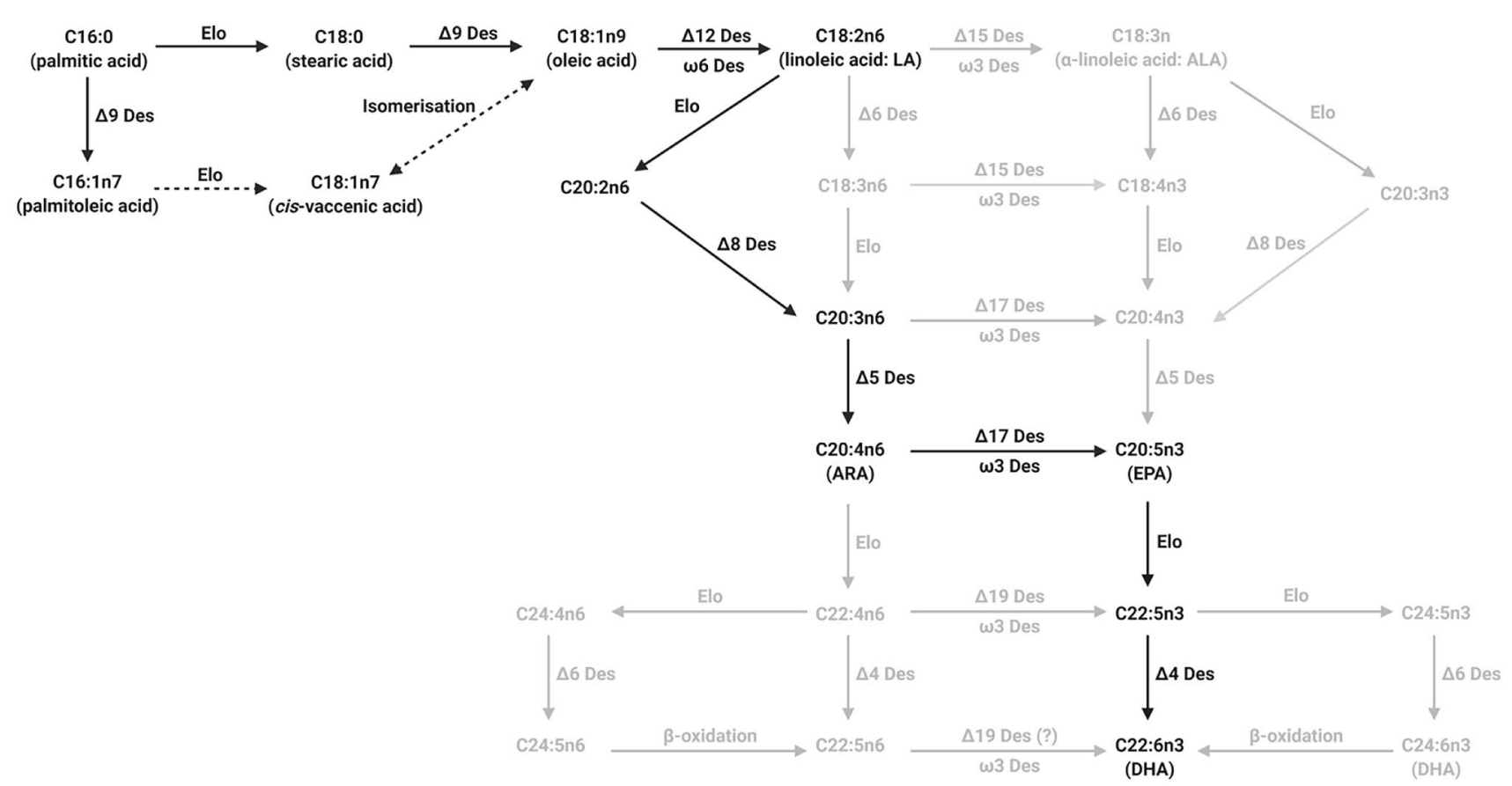

Fig. 4 The hypothesised PUFA biosynthetic pathways in Alitta virens. Likely pathways are shown in bold, whereas pathways that do not appear to be readily utilised are shown in light grey for compari- son. Dotted line represents where further investigations are required for pathway clarification

Denmark, where annual production can reach $23.73 \mathrm{~g}$ ash free dry weigh $\mathrm{m}^{-2}$. This converts to $107.75 \mathrm{~g}$ wet weight $\mathrm{m}^{-2}$ using the EPA data from the present study, which is calculated to be $175.841 \mathrm{~kg} \mathrm{~km}^{-2} \mathrm{y}^{-1}$ or $0.176 \mathrm{~g} \mathrm{~m}^{-2} \mathrm{y}^{-1}$ in terms of wet weight. These calculations suggest that in a typical population their contribution of EPA to the whole ecosystem could reach more than $100 \mathrm{~kg}$ EPA per $\mathrm{km}^{2}$ per annum $\left(0.1 \mathrm{~g} \mathrm{~m}^{-2} \mathrm{y}^{-1}\right)$. These worms are an important food source for numerous bird and fish species, therefore their EPA would be readily transferred throughout the food web. Further, the abilities of these animals to synthesise long-chain PUFA suggests an enhanced role in integrated aquaculture production systems. Tacon (2011) estimated that 0.78 million tonnes of marine fish oil were consumed in 2008 by the aquaculture industry which may not be sustainable (Naylor et al. 2000). To supplement fish oil derived from pelagic fisheries, more diverse production systems are needed (Olive 1999; Klinger and Naylor 2012; Tocher et al. 2019) and worm species could provide such a role as they are easily incorporated into recirculating aquaculture systems (Fidalgo e Costa 1999; García-Alonso et al. 2008; Brown et al. 2011), potentially yielding valuable fatty acids in addition to remediating waste organics (Marques et al. 2018; Pombo et al. 2018; Gómez et al. 2019; Wang et al. 2019). containing these worms. For Alitta virens, we use data of Kristensen (1984b) for production in Norsminde Fjord, 
Supplementary Information The online version contains supplementary material available at https://doi.org/10.1007/s00227-021-03874-3.

Acknowledgements The technical assistance of B. Barlow, P. Donohoe, and D. Whitaker of Newcastle University and R. Rojanathanes of Chulalongkorn University, Thailand and gratefully acknowledged. We thank Natalie Waite for assistance with R.

Author contributions The study was originally conceived by PJWO, MGB and GSC and extended and conducted by SP. Data were collected and analysed by SP and interpreted by all authors. SP and GSC wrote the manuscript.

Funding This research was supported through a Ph.D. scholarship to SP from the Royal Thai Government and Office of Higher Education Commission, Thailand.

Data availability All data generated or analysed during this study are included in this published article [and its supplementary information files].

\section{Declarations}

Conflict of interest All authors declare that they have no conflicts of interest.

Ethical approval This study was approved by the Ethics in Research Committee, Newcastle University. This article does not contain any studies with animals that are regulated under national or EU ethical guidelines.

Open Access This article is licensed under a Creative Commons Attribution 4.0 International License, which permits use, sharing, adaptation, distribution and reproduction in any medium or format, as long as you give appropriate credit to the original author(s) and the source, provide a link to the Creative Commons licence, and indicate if changes were made. The images or other third party material in this article are included in the article's Creative Commons licence, unless indicated otherwise in a credit line to the material. If material is not included in the article's Creative Commons licence and your intended use is not permitted by statutory regulation or exceeds the permitted use, you will need to obtain permission directly from the copyright holder. To view a copy of this licence, visit http://creativecommons.org/licenses/by/4.0/.

\section{References}

Aberle N, Witte U (2003) Deep-sea macrofauna exposed to a simulated sedimentation event in the abyssal NE Atlantic: in situ pulse-chase experiments using 13C-labelled phytodetritus. Mar Ecol Prog Ser 251:37-47. https://doi.org/10.3354/meps251037

Alhazzaa R, Bridle AR, Nichols PD, Carter CG (2011) Up-regulated desaturase and elongase gene expression promoted accumulation of polyunsaturated fatty acid (PUFA) but not long-chain PUFA in Lates calcarifer, a tropical euryhaline fish, fed a stearidonic acid- and $\gamma$-linoleic acid-enriched diet. J Agric Food Chem 59:8423-8434. https://doi.org/10.1021/jf201871w

Arts MT, Brett MT, Kainz M (2009) Lipids in aquatic ecosystems. Springer-Verlag, New York

Ashforth EJ, Olive PJW, Ward AC (2011) Phylogenetic characterisation of bacterial assemblages and the role of sulphur-cycle bacteria in an Arenicola marina bioturbated mesocosm. Mar Ecol Prog Ser 439:19-30. https://doi.org/10.3354/meps09302

Bell MV, Dick JR, Anderson TR, Pond DW (2007) Application of liposome and stable isotope tracer techniques to study polyunsaturated fatty acid biosynthesis in marine zooplankton. J Plankton Res 29:417-422. https://doi.org/10.1093/plankt/ fbm025

Bell MV, Tocher DR (2009) Biosynthesis of polyunsaturated fatty acids in aquatic ecosystems: general pathways and new directions. In: Kainz M, Brett MT, Arts MT (eds) NY Lipids in aquatic ecosystems, Springer, New York, pp 211-236

Bentley MG, Clark S, Pacey AA (1990) The role of arachidonic acid and eicosatrienoic acids in the activation of spermatozoa in Arenicola marina L. (Annelida: Polychaeta). Biol Bull 178:1-9

Bentley MG, Hardege JD (1996) The role of a fatty acid hormone in the reproduction of the polychaete Arenicola marina (L.). Invertebr Reprod Dev 30:159-165

Berg JM, Tymoczko JL, Stryer L (2012) Biochemistry, 7th edn. W.H Freeman and Company

Bischoff AA, Fink P, Waller U (2009) The fatty acid composition of Nereis diversicolor cultured in an integrated recirculated system: possible implications for aquaculture. Aquaculture 296:271-276. https://doi.org/10.1016/j.aquaculture.2009.09.002

Blomquist GJ, Borgeson CE, Vundla M (1991) Polyunsaturated fatty acids and eicosanoids in insects. Insect Biochem 21:99-106. https://doi.org/10.1016/0020-1790(91)90069-Q

Bostrom K, Wettesten M, Boren J, Bondjers G, Wiklund O, Olofsson SO (1986) Pulse-chase studies of the synthesis and intracellular transport of apolipoprotein B-100 in Hep G2 cells. J Biol Chem 261:13800-13806

Brock TJ, Browse J, Watts JL (2006) Genetic regulation of unsaturated fatty acid composition in C. elegans. PLoS Genet 2:0997-1005. https://doi.org/10.1371/journal.pgen.0020108

Brock TJ, Browse J, Watts JL (2007) Fatty acid desaturation and the regulation of adiposity in Caenorhabditis elegans. Genetics 176:865-875. https://doi.org/10.1534/genetics.107.071860

Brown N, Eddy S, Plaud S (2011) Utilization of waste from a marine recirculating fish culture system as a feed source for the polychaete worm, Nereis virens. Aquaculture 322-323:177-183. https://doi.org/10.1016/j.aquaculture.2011.09.017

Burdge GC, Calder PC (2005) Conversion of $\alpha$-linolenic acid to longerchain polyunsaturated fatty acids in human adults. Reprod Nutr Dev 45:581-597. https://doi.org/10.1051/rnd:2005047

Chapelle S (1978) The influence of acclimation temperature on the fatty acid composition of an aquatic crustacean (Carcinus maenas). J Exp Zool 204:337-346

Christie WW (1993) Preparation of lipid extracts from tissues. In: Christie WW (ed) Advances in lipid methodology, Dundee, UK, pp 195-213

Costa LFC, Monroig O, Leaver MJ, Wilson J, Cunha I, Tocher DR (2012) Functional desaturase fads1 ( $\delta 5)$ and fads2 ( $\delta 6)$ orthologues evolved before the origin of jawed vertebrates. PLoS ONE 7:e31950. https://doi.org/10.1371/journal.pone.0031950

Dale H, Solan M, Lam P, Cunliffe M (2019) Sediment microbial assemblage structure is modified by marine polychaete gut passage. FEMS Microbiol Ecol 95:fiz047. https://doi.org/10.1093/femsec/ fiz047

Dass C (2007) Fundamentals of contemporary mass spectrometry. John Wiley \& Sons Inc, US

de Kroon AIPM (2017) Lipidomics in research on yeast membrane lipid homeostasis. Biochem Biophys Acta 1862:797-799. https:// doi.org/10.1016/j.bbalip.2017.02.007

De Troch M, Boeckx P, Cnudde C, Van Gansbeke D, Vanreusel A, Vincx M, Caramujo MJ (2012) Bioconversion of fatty acids at the basis of marine food webs: Insights from a compound-specific 
stable isotope analysis. Mar Ecol Prog Ser 465:53-67. https:// doi.org/10.3354/meps09920

Dolbeth M, Cusson M, Sousa R, Pardal MA (2012) Secondary production as a tool for better understanding of aquatic ecosystems. Can J Fish Aquat Sci 69:1230-1253. https://doi.org/10.1139/ F2012-050

Du Clos KT, Lindsay SM, Jumars PA (2013) Spatial distribution of Alitta virens and Clymenella torquata with respect to rigid boundaries in mud and sand. J Mar Res 71:211-226. https://doi. org/10.1357/002224013807719482

Duangchinda T (2007) Aspects of fatty acids of cultured lugworms (Arenicola marina L.) and their potential role in aquaculture. . $\mathrm{Ph}$. D. Thesis, Newcastle University, UK

Fidalgo e Costa P (1999) Reproduction and growth in captivity of the polychaete Nereis diversicolorO. F. Muller, 1776, using two different kinds of sediment: preliminary assays. Boletin - Instituto Espanol de Oceanografia 15:351-355

Fidalgo e Costa P, Narciso L, Cancela da Fonseca L (2000) Growth, survival and fatty acid profile of Nereis diversicolor(O. F. Muller, 1776) fed on six different diets. Bull Marine Sci 67:337-343

Folch J, Lees M, Sloane Stanley GH (1957) A simple method for the isolation and purification of total lipides from animal tissues. $\mathrm{J}$ Biol Chem 226:497-509

Franz-Odendaal TA, Hockman D (2019) Non-model organisms and unique approaches are needed for the future of evo-devo. Dev Dyn 248:618-619. https://doi.org/10.1002/dvdy.71

Fuchs J, Böhme S, Oswald F, Hedde PN, Krause M, Wiedenmann J, Nienhaus GU (2010) A photoactivatable marker protein for pulse-chase imaging with superresolution. Nat Methods 7:627630. https://doi.org/10.1038/nmeth.1477

Galloway AWE, Budge SM (2020) The critical importance of experimentation in biomarker-based trophic ecology. Phil Trans R Soc B: Biol Sci 375:20190638. https://doi.org/10.1098/rstb.2019. 0638

Galloway AWE, Lowe AT, Sosik EA, Yeung JS, Duggins DO (2013) Fatty acid and stable isotope biomarkers suggest microbeinduced differences in benthic food webs between depths. Limnol Oceanogr 58:1451-1462. https://doi.org/10.4319/lo.2013. 58.4.1451

García-Alonso J, Müller CT, Hardege JD (2008) Influence of food regimes and seasonality on fatty acid composition in the ragworm. Aquat Biol 4:7-13. https://doi.org/10.3354/ab00090

Garrido D, Kabeya N, Hontoria F, Navarro JC, Reis DB, Martín MV, Rodríguez C, Almansa E, Monroig Ó (2019) Methyl-end desaturases with $\Delta 12$ and $\omega 3$ regioselectivities enable the de novo PUFA biosynthesis in the cephalopod Octopus vulgaris. Biochimica et Biophysica Acta - Molecular and Cell Biology of Lipids 1864:1134-1144. https://doi.org/10.1016/j.bbalip.2019. 04.012

Gómez S, Hurtado CF, Orellana J (2019) Bioremediation of organic sludge from a marine recirculating aquaculture system using the polychaete Abarenicola pusilla (Quatrefages, 1866). Aquaculture 507:377-384. https://doi.org/10.1016/j.aquaculture.2019.04.033

Hall JM, Parrish CC, Thompson RJ (2002) Eicosapentaenoic acid regulates scallop (Placopecten magellanicus) membrane fluidity in response to cold. Biol Bull 202:201-203

Hashimoto K, Yoshizawa AC, Saito K, Yamada T, Kanehisa M (2006) The repertoire of desaturases for unsaturated fatty acid synthesis in 397 genomes. Genome Informatics International Conference on Genome Informatics 17:173-183

Hashimoto K, Yoshizawa AC, Okuda S, Kuma K, Goto S, Kanehisa M (2008) The repertoire of desaturases and elongases reveals fatty acid variations in 56 eukaryotic genomes. J Lipid Res 49:183191. https://doi.org/10.1194/jlr.M700377-JLR200

He HT, Finne J, Goridis C (1987) Biosynthesis, membrane association, and release of N-CAM-120, a phosphatidylinositol-linked form of the neural cell adhesion molecule. J Cell Biol 105:2489-2500. https://doi.org/10.1083/jcb.105.6.2489

Herringshaw LG, Sherwood OA, McIlroy D (2010) Ecosystem engineering by bioturbating polychaetes in event bed microcosms. Palaios 25:46-58. https://doi.org/10.2110/palo.2009.p09-055r

Hochstein R, Zhang Q, Sadowsky MJ, Forbes VE (2019) The deposit feeder Capitella teleta has a unique and relatively complex microbiome likely supporting its ability to degrade pollutants. Sci Total Environ 670:547-554. https://doi.org/10.1016/j.scito tenv.2019.03.255

Hughes AD, Cook EJ, Orr H, Kelly MS, Black KD (2011) The transformation of long chain polyunsaturated fatty acids in benthic food webs: The role of sea urchins. J Exp Mar Biol Ecol 409:229-234. https://doi.org/10.1016/j.jembe.2011.08.027

Islam M (2001) A study of the lipid composition of cultured Nereis virens Sars and Arenicola marina L. (Annelida: Polychaeta) in relation to their use in aquaculture maturation diets. Ph. D. Thesis, Newcastle University, UK

Kabeya N, Fonseca MM, Ferrier DEK, Navarro JC, Bay LK, Francis DS, Tocher DR, Castro LFC, Monroig O (2018) Genes for de novo biosynthesis of omega- 3 polyunsaturated fatty acids are widespread in animals. Sci Adv 4:eaar6849. https://doi.org/10. 1126/sciadv.aar6849

Kaneda T (1991) Iso- and anteiso-fatty acids in bacteria: biosynthesis, function, and taxonomic significance. Microbiol Rev 55:288-302

Kelly JR, Scheibling RE (2012) Fatty acids as dietary tracers in benthic food webs. Mar Ecol Prog Ser 446:1-22. https://doi.org/10.3354/ meps09559

Klinger D, Naylor R (2012) Searching for solutions in aquaculture: charting a sustainable course. Ann Rev Environ Resour 37(1):247-276

Kozin VV, Kostyuchenko RP (2015) Vasa, PL10, and Piwi gene expression during caudal regeneration of the polychaete annelid Alitta virens. Dev Genes Evol 225:129-138. https://doi.org/10.1007/ s00427-015-0496-1

Kristensen E (1984a) Life cycle, growth and production in estuarine populations of the polychaetes Nereis virens and $N$. diversicolor. Ecography 7:249-250. https://doi.org/10.1111/j.1600-0587. 1984.tb01128.x

Kristensen E (1984b) Life cycle, growth and production in estuarine populations of the polychaetes Nereis virens and $N$. diversicolor. Holarct Ecol 7:249-256

Kristensen E, Jensen MH, Andersen TK (1985) The impact of polychaete (Nereis virens Sars) burrows on nitrification and nitrate reduction in estuarine sediments. J Exp Mar Biol Ecol 85:75-91. https://doi.org/10.1016/0022-0981(85)90015-2

Lacoste É, Piot A, Archambault P, McKindsey CW, Nozais C (2018) Bioturbation activity of three macrofaunal species and the presence of meiofauna affect the abundance and composition of benthic bacterial communities. Mar Environ Res 136:62-70. https:// doi.org/10.1016/j.marenvres.2018.02.024

Lazo JP, Davis DA (2000) Encyclopedia of aquaculture. John Wiley $\&$ Sons Inc, New York

Levis R, Penman S (1977) The metabolism of poly(A)+ and poly(A)hnRNA in cultured Drosophila cells studied with a rapid uridine pulse-chase. Cell 11:105-113. https://doi.org/10.1016/00928674(77)90321-X

Limsuwatthanathamrong M, Sooksai S, Chunhabundit S, Noitung S, Ngamrojanavanich N, Petsom A (2012) Fatty acid profile and lipid composition of farm-raised and wild-caught sandworms, Perinereis nuntia, the diet for marine shrimp broodstock. Asian J Animal Sci 6:65-75. https://doi.org/10.3923/ajas.2012.65.75

Liu H, Wang H, Cai S, Zhang H (2017) A novel $\omega 3$-desaturase in the deep sea giant tubeworm Riftia pachyptila. Mar Biotechnol 19:345-350. https://doi.org/10.1007/s10126-017-9753-9 
Malcicka M, Ruther J, Ellers J (2017) De novo synthesis of linoleic acid in multiple Collembola species. J Chem Ecol 43:911-919. https://doi.org/10.1007/s10886-017-0878-0

Marques B, Lillebø AI, Ricardo F, Nunes C, Coimbra MA, Calado R (2018) Adding value to ragworms (Hediste diversicolor) through the bioremediation of a super-intensive marine fish farm. Aquac Environ Interact 10:79-88. https://doi.org/10.3354/aei00255

Marty Y, Delaunay F, Moal J, Samain JF (1992) Changes in the fatty acid composition of Pecten maximus (L.) during larval development. J Exp Mar Biol Ecol 163:221-234. https://doi.org/10.1016/ 0022-0981(92)90051-B

McLenaghan NA, Christina Tyler A, Mahl UH, Howarth RW, Marino RM (2011) Benthic macroinvertebrate functional diversity regulates nutrient and algal dynamics in a shallow estuary. Mar Ecol Prog Ser 426:171-184. https://doi.org/10.3354/meps09029

Menzel R, von Chrzanowski H, Tonat T, van Riswyck K, Schliesser P, Ruess L (2019) Presence or absence? Primary structure, regioselectivity and evolution of $\Delta 12 / \omega 3$ fatty acid desaturases in nematodes. Biochimica et Biophysica Acta (BBA) 1864:1194-1205. https://doi.org/10.1016/j.bbalip.2019.05.001

Metz JG, Roessler P, Facciotti D, Levering C, Dittrich F, Lassner M, Valentine R, Lardizabal K, Domergue F, Yamada A, Yazawa K, Knauf V, Browse J (2001) Production of polyunsaturated fatty acids by potyketide synthases in both prokaryotes and eukaryotes. Science 293:290-293. https://doi.org/10.1126/science. 1059593

Meunpol O, Meejing P, Piyatiratitivorakul S (2005) Maturation diet based on fatty acid content for male Penaeus monodon (Fabricius) broodstock. Aquac Res 36:1216-1225. https://doi.org/10. 1111/j.1365-2109.2005.01342.x

Meunpol O, Duangjai E, Yoonpun R, Piyatiratitivorakul S (2010) Detection of prostaglandin E2 in polychaete Perinereis sp. and its effect on Penaeus monodon oocyte development in vitro. Fish Sci 76:281-286. https://doi.org/10.1007/s12562-009-0208-8

Miliou H, Fintikaki M, Tzitzinakis M, Kountouris T, Verriopoulos G (2006) Fatty acid composition of the common octopus, Octopus vulgaris, in relation to rearing temperature and body weight. Aquaculture 256:311-322. https://doi.org/10.1016/j.aquaculture. 2006.02.050

Miyatake T, Moerdijk-Poortvliet TCW, Stal LJ, Boschker HTS (2014) Tracing carbon flow from microphytobenthos to major bacterial groups in an intertidal marine sediment by using an in situ 13C pulse-chase method. Limnol Oceanogr 59:1275-1287. https:// doi.org/10.4319/lo.2014.59.4.1275

Monroig Ó, Guinot D, Hontoria F, Tocher DR, Navarro JC (2012a) Biosynthesis of essential fatty acids in Octopus vulgaris (Cuvier, 1797): Molecular cloning, functional characterisation and tissue distribution of a fatty acyl elongase. Aquaculture 360-361:4553. https://doi.org/10.1016/j.aquaculture.2012.07.016

Monroig Ó, Navarro JC, Dick JR, Alemany F, Tocher DR (2012b) Identification of a $\Delta 5$-like fatty acyl desaturase from the cephalopod Octopus vulgaris (Cuvier 1797) involved in the biosynthesis of essential fatty acids. Mar Biotechnol 14:411-422. https://doi.org/ 10.1007/s10126-011-9423-2

Monroig Ó, Tocher DR, Navarro JC (2013) Biosynthesis of polyunsaturated fatty acids in marine invertebrates: recent advances in molecular mechanisms. Mar Drugs 11:3998-4018. https://doi. org/10.3390/md11103998

Naylor RL, Goldburg RJ, Primavera JH, Kautsky N, Beveridge MCM, Clay J, Folke C, Lubchenco J, Mooney H, Troell M (2000) Effect of aquaculture on world fish supplies. Nature 405:1017-1024. https://doi.org/10.1038/35016500

Nelson GJ (1992) Dietary fatty acids and lipid metabolism. Marcel Dekker Inc, New York

Nelson DL, Cox MM (2008) Lehninger's principles of biochemistry, 5th edn. W.H. Freeman, USA
Nichols DS (2003) Prokaryotes and the input of polyunsaturated fatty acids to the marine food web. FEMS Microbiol Lett 219:1-7. https://doi.org/10.1016/S0378-1097(02)01200-4

Oakes JM, Rysgaard S, Glud RN, Eyre BD (2016) The transformation and fate of sub-Arctic microphytobenthos carbon revealed through 13C-labeling. Limnol Oceanogr 61:2296-2308. https:// doi.org/10.1002/lno.10377

Olive PJW (1993) Management of the exploitation of the lugworm Arenicola marina and the ragworm Nereis virens (Polychaeta) in conservation areas. Aquat Conserv Mar Freshwat Ecosyst 3:1-24. https://doi.org/10.1002/aqc.3270030102

Olive PJW (1999) Polychaete aquaculture and polychaete science: a mutual synergism. Hydrobiologia 402:175-183. https://doi.org/ 10.1023/A:1003744610012

Olive PJW, Duangchinda T, Ashforth E, Craig S, Ward AC, Davies SJ (2009) Net gain of long-chain polyunsaturated fatty acids (PUFA) in a lugworm Arenicola marina bioturbated mesocosm. Mar Ecol Prog Ser 387:223-239. https://doi.org/10.3354/meps0 8088

Pairohakul S (2013) Evidence for polyunsaturated fatty acid biosynthesis in the Ragworm (Nereis virens) and the Lugworm (Arenicola marina). School of Marine Science and Technology, UK

Pazos AJ, Ruíz C, García-Martín O, Abad M, Sánchez JL (1996) Seasonal variations of the lipid content and fatty acid composition of Crassostrea gigas cultured in El Grove, Galicia, N.W. Spain. Comp Biochem Physiol B Biochem Mol Biol 114:171-179. https://doi.org/10.1016/0305-0491(96)00017-X

Pini JM, Richir J, Watson GJ (2015) Metal bioavailability and bioaccumulation in the polychaete Nereis (Alitta) virens (Sars): The effects of site-specific sediment characteristics. Mar Pollut Bull 95:565-575. https://doi.org/10.1016/j.marpolbul.2015.03.042

Pirini M, Manuzzi MP, Pagliarani A, Trombetti F, Borgatti AR, Ventrella V (2007) Changes in fatty acid composition of Mytilus galloprovincialis (Lmk) fed on microalgal and wheat germ diets. Comp Biochem Physiol B Biochem Mol Biol 147:616-626. https://doi.org/10.1016/j.cbpb.2007.04.003

Pitt KA, Connolly RM, Meziane T (2009) Stable isotope and fatty acid tracers in energy and nutrient studies of jellyfish: a review. Hydrobiologia 616:119-132. https://doi.org/10.1007/ s10750-008-9581-z

Pombo A, Baptista T, Granada L, Ferreira SMF, Gonçalves SC, Anjos C, Erica S, Chainho P, Cancela da Fonseca L, Fidalgo e Costa P, Costa JL (2018) Insight into aquaculture's potential of marine annelid worms and ecological concerns: a review. Rev Aquaculture. https://doi.org/10.1111/raq.12307

Ran Z, Xu J, Liao K, Monroig Ó, Navarro JC, Oboh A, Jin M, Zhou Q, Zhou C, Tocher DR, Yan X (2019) Biosynthesis of long-chain polyunsaturated fatty acids in the razor clam Sinonovacula constricta: Characterization of four fatty acyl elongases and a novel desaturase capacity. Biochem Biophys Acta 1864:1083-1090. https://doi.org/10.1016/j.bbalip.2019.04.004

Riekenberg PM, Oakes JM, Eyre BD (2018) Short-term fate of intertidal microphytobenthos carbon under enhanced nutrient availability: a 13C pulse-chase experiment. Biogeosciences 15:28732889. https://doi.org/10.5194/bg-15-2873-2018

Seemann J, Berry KL, Carballo-Bolaños R, Struck U, Leinfelder RR (2013) The use of $13 \mathrm{C}$ and $15 \mathrm{~N}$ isotope labeling techniques to assess heterotrophy of corals. J Exp Mar Biol Ecol 442:88-95. https://doi.org/10.1016/j.jembe.2013.01.004

Silverstein RM, Webster FX, Kiemle D (2005) Spectrometric identification of organic compounds, 7th edn. John Wiley \& Sons Inc, Hoboken, NJ

Simakov O, Marletaz F, Cho SJ, Edsinger-Gonzales E, Havlak P, Hellsten U, Kuo DH, Larsson T, Lv J, Arendt D, Savage R, Osoegawa K, De Jong P, Grimwood J, Chapman JA, Shapiro H, Aerts A, Otillar RP, Terry AY, Boore JL, Grigoriev IV, Lindberg DR, 
Seaver EC, Weisblat DA, Putnam NH, Rokhsar DS (2013) Insights into bilaterian evolution from three spiralian genomes. Nature 493:526-531. https://doi.org/10.1038/nature11696

Skrzypski J, Bellenger S, Bellenger J, Sinclair A, Poisson JP, Tessier C, Rialland M, Narce M (2009) Revisiting delta-6 desaturase regulation by $\mathrm{C} 18$ unsaturated fatty acids, depending on the nutritional status. Biochimie 91:1443-1449. https://doi.org/10. 1016/j.biochi.2009.08.001

Stanley DW (2000) Eicosanoids in invertebrate signal transduction systems. Princeton University Press, Princeton, New Jersey

Stanley DW, Howard RW (1998) The biology of prostaglandins and related eicosanoids in invertebrates: cellular, organismal and ecological actions. Am Zool 38:369-381

Stanley-Samuelson DW (1987) Physiological roles of prostaglandins and other eicosanoids in invertebrates. Biol Bull 173:92-102

Tacon AGJ (2011) Demand and supply of feed ingredients for farmed fish and crustaceans: trends and prospects. FAO Fisheries and Aquaculture Technical Paper, Vol 564, Rome

Taghon GL (1988) Phospholipid fatty acid composition of the deepsea hydrothermal vent polychaete Paralvinella palmiformis (Polychaeta-ampharetidae): effects of thermal regime and comparison with two shallow-water confamilial species. Comp Biochem Physiol B: Biochem 91:593-596. https://doi.org/10.1016/ 0305-0491(88)90027-2

Tita G, Desrosiers G, Vincx M, Nozais C (2000) Predation and sediment disturbance effects of the intertidal polychaete Nereis virens (Sars) on associated meiofaunal assemblages. J Exp Mar Biol Ecol 243:261-282. https://doi.org/10.1016/S0022-0981(99) 00116-1

Tocher DR (2015) Omega-3 long-chain polyunsaturated fatty acids and aquaculture in perspective. Aquaculture 449:94-107. https://doi. org/10.1016/j.aquaculture.2015.01.010

Tocher DR, Betancor MB, Sprague M, Olsen RE, Napier JA (2019) Omega-3 long-chain polyunsaturated fatty acids, EPA and DHA: bridging the gap between supply and demand. Nutrients. https:// doi.org/10.3390/nu11010089
Wang H, Seekamp I, Malzahn A, Hagemann A, Carvajal AK, Slizyte R, Standal IB, Handå A, Reitan KI (2019) Growth and nutritional composition of the polychaete Hediste diversicolor (OF Müller, 1776) cultivated on waste from land-based salmon smolt aquaculture. Aquaculture 502:232-241. https://doi.org/10.1016/j. aquaculture.2018.12.047

Watson GJ, Murray JM, Schaefer M, Bonner A (2017) Bait worms: a valuable and important fishery with implications for fisheries and conservation management. Fish Fish 18:374-388. https:// doi.org/10.1111/faf.12178

Watson GJ, Pini JM, Richir J (2018) Chronic exposure to copper and zinc induces DNA damage in the polychaete Alitta virens and the implications for future toxicity of coastal sites. Environ Pollut 243:1498-1508. https://doi.org/10.1016/j.envpol.2018.09.091

Watts JL (2009) Fat synthesis and adiposity regulation in Caenorhabditis elegans. Trends Endocrinol Metab 20:58-65. https://doi. org/10.1016/j.tem.2008.11.002

Watts JL, Browse J (2002) Genetic dissection of polyunsaturated fatty acid synthesis in Caenorhabditis elegans. Proc Natl Acad Sci USA 99:5854-5859. https://doi.org/10.1073/pnas.092064799

Wilkinson DJ (2018) Historical and contemporary stable isotope tracer approaches to studying mammalian protein metabolism. Mass Spectrom Rev 37:57-80. https://doi.org/10.1002/mas.21507

Zhukova NV, Imbs AB, Yi LF (1998) Diet-induced changes in lipid and fatty acid composition of Artemia salina. Comp Biochem Physiol B Biochem Mol Biol 120:499-506. https://doi.org/10. 1016/S0305-0491(98)10036-6

Publisher's Note Springer Nature remains neutral with regard to jurisdictional claims in published maps and institutional affiliations. 